\title{
CROSS-BREEDING EXPERIMENTS ON SOME IMPORTANT FISHES OF FAMILY CICHLIDAE (GENUS OREOCHROMIS) AND EVALUATION OF THEIR HYBRIDS.
}

\section{Mohamed A. Essa and Mary R. Haroun}

National Institute of Oceanography and Fisheries, kayet Bey, Alexandria, Egypt.

Key words: Cross-breeding, tilapia, Oreochromis, hybrids, growth performance, survival, heterosis.

(Received May 5, 1998)

\section{ABSTRACT}

T he breeding characteristics, growth performance, survival rate and feed conversion ratio of the three species of Nile tilapia (Oreochromis niloticus), blue tilapia ( $O$. aureus), red tilapia (Oreochromis sp.) and their different combination crosses were investigated. The present study emonstrates that: 1) the growth rates of $O$. aureus and red tilapia brood fish females were improved when they were crossed with males of $O$. niloticus; 2) the mean number of fry produced by females of $O$. niloticus was 1.2 and 1.3 times as that from $O$. aureus and red tilapia, respectively; 3) red tilapia inherited cold tolerance trait by back crossing with males $O$. aureus. This trait was transferred from $O$. cuureus to a cold sensitive population of red tilapia; and 4) the hybrids of $O$. niloticus females $\times$ O. aureus males; red tilapia females $\times$ O. niltoicus males, $O$. aureus females $\times O$. niloticus males, and red tilapia females $\times O$. aureus males exhibited positive heterosis values (hybrid vigour) in growth parameters and survival rate. Also, these hybrids used less feed to produce one unit of gain in body weight than their parents. Thereby, these hybrids were judged to be of high potential commercial value in fish farming. 


\section{INTRODUCTION}

Aquacultural organisms have very high reproductive rates and large phenotypic variance (Moav, 1976). This combination makes mass selection and hybridization for large size an easy task. Hybridization and selection are the principle means of fish improvement (kirpichnikov, 1971 and Zaki et al., 1987). Hybridization is aimed to evolve a hybrid or strain of superior quality than the parent species. Thus the hybrids play an important role in fish culture (Essa, 1987).

During the past few years the genetic and breeding research on tilapia is limited to the four important mouth-brooding used in aquaculture: Oreochromis niloticus, $O$. aureus, $O$. mosambicus and $O$. urolepis hornorum. It covered research on: the inheritance of qualitative phenotypes; strains evaluations; heritabilities; in-breeding; environmental factors that influence genetic studies; manipulation of chromosome number; and interspecific hybridization to produce all male populations (Wohlfarth and Hulata, 1983; Behrends, 1983; Behrends and Smitherman, 1984; Tave, 1988; Doudet, 1992; El-Deeb and Essa, 1992; Gourene and Teugels, 1993 as well as Hulata et al., 1993).

This study was undertaken to evaluate the value of hybridization in three important fishes of family Cichildae (Genus Oreochromis): Nile tilapia (Oreochromis niloticus), blue tilapia (O. aureus), red tilapia, Oreochromis sp. as well as their different combination crosses. The traits compared included in addition to growth performance, survival rate and feed conversion ratio during nursing period. The heterosis values were also considered.

\section{MATERIAL AND METHODS}

The present study was conducted for 90 days at Alexandria Governorate Fish farm, Fry Production Unit. 
Three tilapia species were used for producing hybrid progenies:

1) Nile tilapia (Oreochromis niloticus): this is considered a fast growing species (Bardach et al., 1972);

2) Blue tilapia ( $O$. aureus): this is considered more cold tolerant than both $O$. niloticus and red tilapia (Behrends and Smitherman, 1984)

3) Red tilapia (Oreochromis sp.): a collective name for a large number of red, orange, gold and pink phynotypes. Red tilapia is a hybrid produced by the interbreeding between $O$. niloticus and the mutant of $O$. mossambictus (Liao and Chang, 1983). The stock in our study was introduced from Florida, USA (Florida strain) by Mariut Fish Farming Company, Alexandria.

Ripe females and males tilapias of different species were stocked into $6 \mathrm{~m}^{2}$ concrete ponds in April, 1997 at rate of 4 breeders $/ \mathrm{m}^{2}$. The sex ratio of the fish was three females to one male. Males and females of comparable size and weight were stocked together to reduce injuries to females caused by male aggressiveness during spawning behavior. Breeders of tilapias with mean weights of $47.29 \pm 3.47$ (female) and $72.79 \pm 7.45$ (male) were used during the present study. The spawners were supplementary fed with commercially available pellets $(32.58 \%$ protein) at the rates of $1.5 \%$ of their body weight/day (Table 1). The temperature of the water in the spawning ponds was $22-31^{\circ} \mathrm{C}$. the oxygen content was not less than $5.0 \mathrm{mg} / \mathrm{l}$ and the $\mathrm{pH}$ was on the alkaline side (7.6-8.5). The spawning period was 25 days.

Fry produced in each pond were collected daily or more often as they appeared at the water surface with a dip net and counted. Dip net collection was supplemented by use of a $2.0 \mathrm{~m}$ long seine with a mesh size of $1.6 \mathrm{~mm}$.

Six different hybrids were tested and evaluated during the present study:

1) Females $O$. niloticus $x$ males Red tilapia.

2) Females Red tilapia $x$ males $O$. niloticus.

3) Females Red tilapia x males $O$. aureus.

4) Females $O$. aureus $\times$ males Red tilapia.

5) Females $O$. niloticus $x$ males $O$. aureus.

6) Females $O$. aureus $x$ males $O$. niloticus. 
Three replicated of each of the six hybrids and parents were stocked into concrete ponds. Complete random design was implemented in placement of fish groups in ponds. Ponds were $2.0 \mathrm{~m} \times 3.0 \mathrm{~m} \times 1.0 \mathrm{~m}\left(6 \mathrm{~m}^{3}\right)$. Daily food allowance for the tilapia groups was based on $10 \%$ of body weight twice a day with $49.47 \%$ crude protein fine commercial diet (Table 1). The duration of theexperimental rearing or nursing period was 90 days.

Young fry of different hybrids combinations were compared for their growth performance, survival percentage, feed conversion ratio and heterosis (hybrid vigour) according to Essa (1987), during nursing period. Samples were taken from each pond bi-weekly. At harvest, fish fingerlings were counted and weighed.

Data were analyzed with one-way analysis of variance (ANOVA), followed by Duncan's multiple range test when differences were indicated.

\section{RESULTS AND DISCUSSION}

\section{Growth and survival percentage in brood fish under six different tilapia crosses conditions}

The fish used as experimental subjects were hybrids of three Tilapia species Oreochromis niloticus, $O$. aureus, red tilapia (Oreochromis sp.). The weight and length gains of the brood fish were different in all six tilapia crosses conditions. The increase in individual weights and lengths in each of the experimental groups has being presented in Table (2). After 25 days spawning period, broodfish in group B (hybrids of red tilapia females and $O$. niloticus males) showed a fastest growth rate than the other five groups. They possessed average weights gain of $49.4 \mathrm{~g}$ and $93.6 \mathrm{~g}$ for females and males, respectively. While the corresponding results for lengths gain were $4.5 \mathrm{~cm}$ and $6.7 \mathrm{~cm}$ for females and males, respectively. It is obvious from Table (2) also that males grow faster than females in tilapias. Similar observations has been shown by Behrends (1983); Tave et al., (1990) as well as Essa and Faltas (1997) for $O$. niloticus and $O$. aureus. This suggests that the differential growth rates have a genetic basis. 

(Genus Oreochromis) and evaluation of their hybrids.

The present study demonstrates also that the growth rates of $O$. aureus and red tilapia brood fish females were improved when they were crossed with males of $O$. niloticus. This might be due to the compatibility behavioral patterns that may be existing between the three tilapia species.

From Table (2) it can be shown that, survival rate was $100 \%$ for all six groups. Therefore, the present data demonstrated the feasibility of using tilapias in fish farming. Wohlfarth et al., (1983) showed that, summer and winter survival rate was over $80 \%$ in the parental species of $O$. niloticus $O$. aureus and O. mossambicus.

\section{Fry production}

The mean number of fry (swim-up stage) produced per female spawner in different hybrid combinations and the parental species is shown in Table (3). The mean number fry produced by the Nile tilapia (O. niloticus) females was 1.2 and 1.3 times as high as that from $O$. aureus and red tilapia females, respectively. While the differences in fry production of $O$. aureus and red tilapia females when spawned with males of different species are insignificant (ranged between 981- 1073 fry/female). This may be attributed to the differences in fecundity due more to the weight of fish stocked than the species of the male fish. These data suggest that female age and size could confound genetic differences when evaluating reproductive performance. Siraj et al., (1983) examined the influence of female age and size on reproductive performance, egg size, fry size and early growth in $O$. nilotiucs. Female age and size were positively correlated with spawning rate, egg length, hatchability and sac fry length and were negatively correlated with number of eggs $/ \mathrm{kg}$ female.Age of fry within the range of 7 to 10 days swim up tested in this experiment did not show a significant difference in the size attained, weight and length (Table 3). The average body weight and length of swim-up fry varied between $0.03-0.05 \mathrm{~g}$ and $0.7-0.9 \mathrm{~cm}$, respectively. A possible explanation to these results are that, the values of the coefficient of similarity and the genetic distance showed close similarity between $O$. nilotcus, $O$. aureus and red tilapia (El-Deeb and Essa, 1992). 


\section{Production performance}

The different hybrids combinations were compared for their growth performance (mean weight and length gains per fish, mean daily weight and

length gains as well as specific growth rate), condition factor, survival percentage and feed conversion ratio and the results are summarized in Tables (4 and 5).

\subsection{Genetic improvement of red tilapia}

The parental specie used for hybridization in this investigation may by divided into two groups, according to their relative tolerance to low water temperature and growth rate (Wohlfarth et al., 1990. El-Deeb and Essa, 1992).

1) The two groups are: High growth and sensitive species or stain: $O$. niloticus and red tilapia

2) Normal growth and relatively resistant species: $O$. aureus.

Hybridization in fish is aimed to evolve a hybrid or strain of superior quality than the parent species. Therefore the following crosses were made:

(a) Back cross was made between red tilapia females and $O$. nilotins males. F1 progeny showed a superior growth rate in weight length and specific growth rate (Table 4) and survival percentage $(83 \%)$ when compared with that of their parents (Table 5). Also, the F1 hybrids used less feed (1.09) to produce one unit of gain in weight than their parents (Table 5). But in case of condition factor, the F1 hybrids showed intermediate inheritance, 2.00 (Table 5).

(b) Back cross between female red tilapia and male $O$. aureus have been carried out in this study to increase red tilapia tolerance to low water temperature and improve growth rate of $O$. aureus. FI progeny showed a superior growth in weight and length compared with that of the maternal species, $O$. aureus (Table 4). Table (5) proves that, the F1 hybrids was the most cold tolerant than their parents, thereby has the highest survival rate $(85 \%)$, best feed conversion ratio and high condition factor (2.00) compared with those of their parents. Lagler (1956) stated that high values of condition factor indicated the suitability of the environment to the fish. It appears also that. cold tolerance is a dominant trait. 

(Genus Oreochromis) and evaluation of their hybrids.

(c) In contrast, when red tilapia males and $O$. niloticus or $O$. aureus females were crossed only survival percentage and feed conversion ratio were improved

in the $F 1$ progeny and the differences between the $F 1$ hybrids and their parents for condition factor were insignificant (Table 5). The cross-breeding of red tilapia males and $O$. niloticus or $O$. aureus females resulted in a very poor growth in weight, length and specific growth rate when compared with those of their parents (Table 4) and the differences were significant $(P \leq 0.05)$.

These data demonstrate that, it is easy to hybridize fishes related to each other. But in some cases, even reciprocal hybrids produced by crossing the same species by a male of another, and vice versa, may be different in fry production, growth in weight and length as well as survival percentage. According to Nikoljukin (1971) and Essa (1987) this might be due to the fact that differences of the reciprocal forms of hybrids are determined by cytoplasmic differences of the crosses species which will result in different interaction of the nucleus and the plasma in reciprocal crossing. This will lead to some viable hybrids and other may not be or at least differ in some quantitative phenotypes characters.

\subsection{Genetic improvement of blue tilapia, $O$. aureus}

A hybrid cross was made between females of Nile tilapia, $O$. niloticus and males of blue tilapia, $O$. aureus. Also, the reciprocal crossing have been carried out in the present study (females $O$. aureus $\times$ males $O$. niloticus). The Fl progenies were compared for the growth performance, condition factor, survival percentage and feed conversion ratio and the results are summarized in

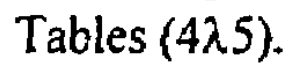

All such F1 progeny (female $O$. niloticus $\mathrm{x}$ males $O$. altreus) grew more rapidly (Table 4 ) and possessed highest survival percentage (91.00\%) as well as best feed conversion ratio (1.13:1) than their parents (Table 5). But the differences in condition factor between the hybrids and their parents were insignificant $(\mathrm{P}>0.05)$. 
The Fl progeny of the reciprocal hybrids (females $O$. cureus $\mathrm{x}$ males $O$. niloticus) exhibited intermediate inheritance for growth in weight and length (Table 4). It has been reported that $O$. aureus is the most cold tolerant species

and $O$. niloticus is the fastest growth fish in genus Oreochromis (Bardach et al., 1972 and Wohlfarth ef al., 1990), therefore it is not surprising to find that the cross-breeding of females $O$. aureus $\times$ males $O$. niloticus exhibited highest survival percentage $(96.00 \%)$ and best feed conversion ratio (1.56) when compared with those of parents Table (5). Bautista et al. (1988) found that the progeny produced by the reciprocal crossing between $O$. niloticus and $O$. aureus had highest survival percentage than parents and did not differ significantly. In contrast, the hybrids have a less value of condition factor (1.83) than those of parents by $13.9 \%$.

The reasons for the differences of the reciprocal forms of $O$. niloticus and $O$. aureus hybrids have been discussed in previous section (3-1) according to Nikoljukin (1971) and Essa (1987).

\section{Heterosis}

The term heterosis (hybrid vigour) characterized the increased ability of a hybrid as compared to the parental line species and this improvement is a result of action and interaction of allelic and non allelic dominance and very often linked genes (Demin, 1971). Growth performance and survival percentage are the most important for evaluation of fish culture and its productivity.

Table (6) shows the heterosis values of mean weight and length gains, specific growth rate and survival rate of crosses of $O$. niloticus $(\mathrm{N})$ and $O$. aureus (A) and red tilapia (R) (Oreochromis sp.) during nursing period (90 days). Positive heterosis values of growth parameters and survival rate were recorded for the cross-bred fingerlings of $\mathrm{R} \times \mathrm{N}, \mathrm{R} \times \mathrm{A}, \mathrm{N} \times \mathrm{A}$ and $\mathrm{A} \times \mathrm{N}$ (the female is first), but negative heterosis values for growth parameters and positive heterosis values for survival rates were showed for the cross-breeding fingerlings of males red tilapia and females $O$. niloticus or $O$. aureus. Furthermore, females red tilapia and males $O$. niloticus backcross hybrids were 
significantly heavier than the females red tilapia and males $O$. aureus backcross hybrids and exhibited higher positive heterosis in mean weighrt gain and specific growth rate. But females red titlapia and males $O$. aureus backcross hybrids showed higher positive heterosis in mean length gain and survival percentage than $\mathrm{R} \times \mathrm{N}$ backcross hybrids. These results might be attributed to 1) O. nilotiucs grow faster than O. aureus (Tave, 1988; El-Deeb and Essa, 1992); and 2) $O$. aureus was more cold tolerant than $O$. niloticus (Behrends and Smitherman, 1984). These results demonstrated that, parental heterosis was responsible for the increased heterosis in the backcross hybrids.

Although the hybrids exhibited heterosis, no hybrid was better than the hybrids produced from crossing females $O$. niloticus and males $O$. aureus (Table 6). Also, the reciprocal crossing $A \times N$ exhibited a good heterosis values. Similar observations and trends have been reported by Macintosh and Silva (1984). They found that, under equivalent conditions, $O$. niloticus female $x \quad O$. aureus male fry had a higher rate of growth, feed conversion and were more uniform in size than the parents and $O$. massambicus fry. According to Hulata et al. (1993), the Nile strain hybrids of $O$. niloticus and $O$. aureus can be considered for commercial hybridization.

The differences among hybrids in the present study can be explained also according to SEAFDEC (1986), in tilapia crosses, some traits of the hybrid were observed to be inherited from the female parent, other from the male parent and a few intermediate inherited traits were observed.

\section{These results suggest that}

1) the hybrids of

$O$. niloticus females $x O$. aureus males.

Red tilapia females $\times O$. niloticus males.

$O$. aureus females $\times O$. niloticus males.

Red tilapia females $\times O$. aureus males.

Thre were judged to be of high potential commercial value in fish farming; 
2) Although the red tilapia hybrid show a bright potential for aquaculture, yet the inheritance of the red pigmentation need further work

3) Much further work is required to investigate the nutritional requirements of all these hybrids.

\section{ACKNOWLEDGEMENTS}

The authors thank Prof. Dr. Fouad Afifi, Fac. Of Science, Tanta University for his advice and assistance Sincere thanks to the staff members of Alexandria Governorate Fish Farm for their help and facilities employed in the present investigation.

\section{References}

Bardach, J.E., J.H. Ryther and W.O. Mclarney (1972). Aquaculture, the farming and husbundry of freshwater and marine organisms. $868 \mathrm{pp}$ WielyInterscience-New York, London.

Bautista, A.M.; M.H. Carlos; B.O. Acosta and P.B. Valera (1988). Cage culture of $O$. aureus and $O$. niloticus hybrids in Laguna Lake, Philippines. J. of Aquaculture in the Tropics, 3(2):77-82.

Behrends, L.L. (1983). Evaluation of hatchery techniques for intraspecific and interspecific seed production in four species of tilapia. Auburn Univ., Alabama USA, 71, P. Ph.D. dissertation.

Behrends, L.L. and R.O. Smitherman (1984). Development of cold-tolerant population of red tilapia through introgressive hybridization. J. World Mariculture, 15:172-178.

Behrends, L.L. and R.O. Smitherman (1988). Genetic and breeding of red tilapia. In: R.O. Smitherman and D. Tave (eds.) proc. Auburn Symp. On Fisheries and Aquaculture. Alabama Agric. Experi. Station. Auburn Univ., Alabama, USA.

Demin, Y.S. (1971). Heterosis. Rep FAO/ UNDP (TA), (2926)P. 109. 
Cross-Breeding experiments on some important fishes of Family Cichlidae

(Genus Oreochromis) and evaluation of their hybrids.

Doudet, T. (1992). Brackish water tolerance of some species and hybrids of Oreochromis for use in Lagoon aquaculture (Ivory coast). Aquaculture, 102 (3): $275-288$.

Dowidar, N.E. and M.A. Essa (1988). Acclimation of red tilapia in Egypt. Proc. $1^{\text {st }}$ Conf. Develop. Fish Resor. 6-8 Aug., Fac. Agric., Alex., Univ.

El-Deeb, S.I. and M.A. Essa (1992). Genetic approach of red tilapia. Bull. Nat. Inst. Oceanogr. Fish., ARE. 18:105-113.

Essa, M.A. (1987). Genetical studies on freshwater fish. Evaluation of hybridization of five important species of cyprinids. Ph.D. Thesis, Fac. Agriculture, Alexandria Univ. Egypt.

Essa, M.A., N.A. Hassan and M.E. Salama (1996). Growth performance and socio-economic feasibility of red tilapia and its black progeny reared in netencosutes. J. Egypt. German Soc. Zool., 19(B):27-44.

Essa, M.M. and S.N. Faltes (1997). Impact of pollution problems on some fishery aspects of tilapia in lake Maruit, Egypt. Proc. Of the $7^{\text {th }}$ Intern. Conf. On Environment protection is a Must, 20-22 May, Alex., Egypt, Organized by Nat. Inst. Oceanogr. Fish and Intern. Scientists Association.

Galman, O.R.; J. Moreau and R. Avalion (1988). Breeding characteristic and growth performance of Philippine red tilapia. P. 169-175. In: R.S.V. Puilin. T. Bhukaswan, K. Tonguthal and J.L. maclean (eds.). the second Inter. Symp. On tilapia in Aquaculture. ICLARM Conf. Proc. 15,623 p. Dept. Fish., Bangkok, Thailand and ICLARM, Manila, Philippines.

Gourene, G. and G.G. Teugels (1993). Morphological differences between some strains of the tilapias, Oreochromis niloticus and $O$. aureus used in fish culture. Cybium, 17(4):343-355.

Hulata, G., G.W. Wohlfarth, I. Karplus, G.L. Schroeder, S. Harpaz, A. Halevy, S. Rothbard, S. Cohen, I. Israel and M. Kavessa (1993). Evaluation of 
$O$. niloticus $\times 0$. aureus hybrid progeny of different geographical isolates, reared under varying management regime. Aquaculture. 115 (3-4):253-271. Kirpichnikov, V.S. (1971). Genetic of the common carp (Cyprinus carpio) and other edible fishes. P. 156 In: Rep. FAO/UNDP (TA), (2926), Rome.

Kuo, H. (1988). Progress in genetic improvement of red tilapia in Taiwan. P. 219-221. In: R.S.V. Pullin, T. Bhukaswan, K. Tonguthal and J.L. Mackan (eds.). the second Intern. Symp on tilapa in aquaculture. ICLARM Proc. 15, 623p. Bangkok, Thailand and ICLARM, Manila, Philippines.

Liao, I.C. and S.H. Chang (1983). Studies on the feasibility of red tilapia culture in saline water. P. 524-533. In: L. Fishelson and Z. Yaron (comps.). Proc. Of the Intern. Symp. On Tilapa in Aquaculture, 8-13 May, Nazareth, Iseral, Tel Aviv Univ., Iseral.

Macintosh, D.J. and S.S. Silva (1984). The influence of stocking density and food ration on fry survival and growth in $O$. mossambicus and $O$. niloticus female $\times 0$. aureus male hybrids reared in a closed circulated system. Aquaculture, $41(4): 345-358$.

Moav, R. (1976). Genetic improvement in Aquaculture industry. FAO Tech. Conf. On Aquacutlre, Kyoto, Japan 26 May, FIR: AQ/Conf/76/R.9, P. 123, Rome.

Nikoljukin, N.I. (1971). Fundamentals of hybridization in fish culture. Rep. FAO/UNDP, (TA), (2926):321-327. Rome.

Seafdec (Southeast, Asian, Fisheries Development Center ) (1984). Development of tilapia broodstock for genetic studies. Aquacultusre Dept. Annual Report 1984. Tigbauan, Iloilo City, Philippines, P. 14. 
Siraj, R.O., S. Castillo-Calluser, and E.A. Dunham (1983). Reproductive traits for three year classes of Tilapia nilotica and maternal effects of their progeny. P. 210-218, In: Proc. Inter. Symp. On Tilapia in Aquaculture. Tel Aviv Univ., Israel.

Tave, D. (1988): Genetic and breeding of tilapia: a review, P. 285-293, In: R.S.V. Pulling T. Bhukasqan, K. Tonguthai and J.L. maclean (eds.). The second Intern. Symp. On Tilapia in Aquaculture. ICLARM Conf. Proc. 15, 623P. Dept. of Fish., Bangkok, Thailand and ICLARM, manila, Philippines.

Tave, D., V. Jayaprakas and R.O. Smitherman (1990). Effects of intraspecific hybridization in Tilapia nilotica on survival under ambient winter temperature in Alabama, USA. J. the World Aquacultre Society, 21 (3):201-204.

Varadaraj, K. (1990). Dominant red colour morphology used to detect paternal contamination in batches of $O$. mossambicus gynogens. Aquaculture and Fisheries Management, 21 (2):163-172.

Wohlfarth, G. and G. Hulata (1983). Applied genetic of tilapias. ICLARM studied and Review 6. International Center For Living Aquatic Resources Management. Manila, Philippines.

Wohlfarth, G. ; G. Hulata and A. Halevy (1990). Growth, survival and sex ratio of some tilapia species and interspecific hybrids. European Aquaculture Society No. 11:87-101, Special Publication.

Zaki, M.I.; M.A. Essa; A.K. Soliman and M.A. Kosba (1987). The viability degree of 15 different kinds of hybrids produced by pairing gamets from common carp, Chinese carps and tench. Bull. Inst. Oceangr. \& Fish., ARE, 13(1):35-42. 
Table (1): The ingredients and chemical analysis of the broodfish and fry diets.

\begin{tabular}{|l|c|c|}
\hline \multicolumn{1}{|c|}{ Ingredients } & $\begin{array}{c}\text { Brood fish } \\
\text { diet (\%) }\end{array}$ & $\begin{array}{c}\text { Fry } \\
\text { diet (\%) }\end{array}$ \\
\hline Soybean meal & 35 & 35 \\
Fish meal & 24 & 35 \\
Wheat bran & 30 & 25 \\
Starch & 10 & 4 \\
Vitamin and minerals mixture & 1 & 1 \\
\hline Chemical analysis: & 91.75 & 92.34 \\
Dry matter & 32.58 & 49.47 \\
Crude protein & 5.28 & 3.92 \\
Crude fat & 10.27 & 4.17 \\
Crude fiber & 41.00 & 33.16 \\
Nitrogen free extract & 10.87 & 9.28 \\
Ash & & \\
\hline
\end{tabular}




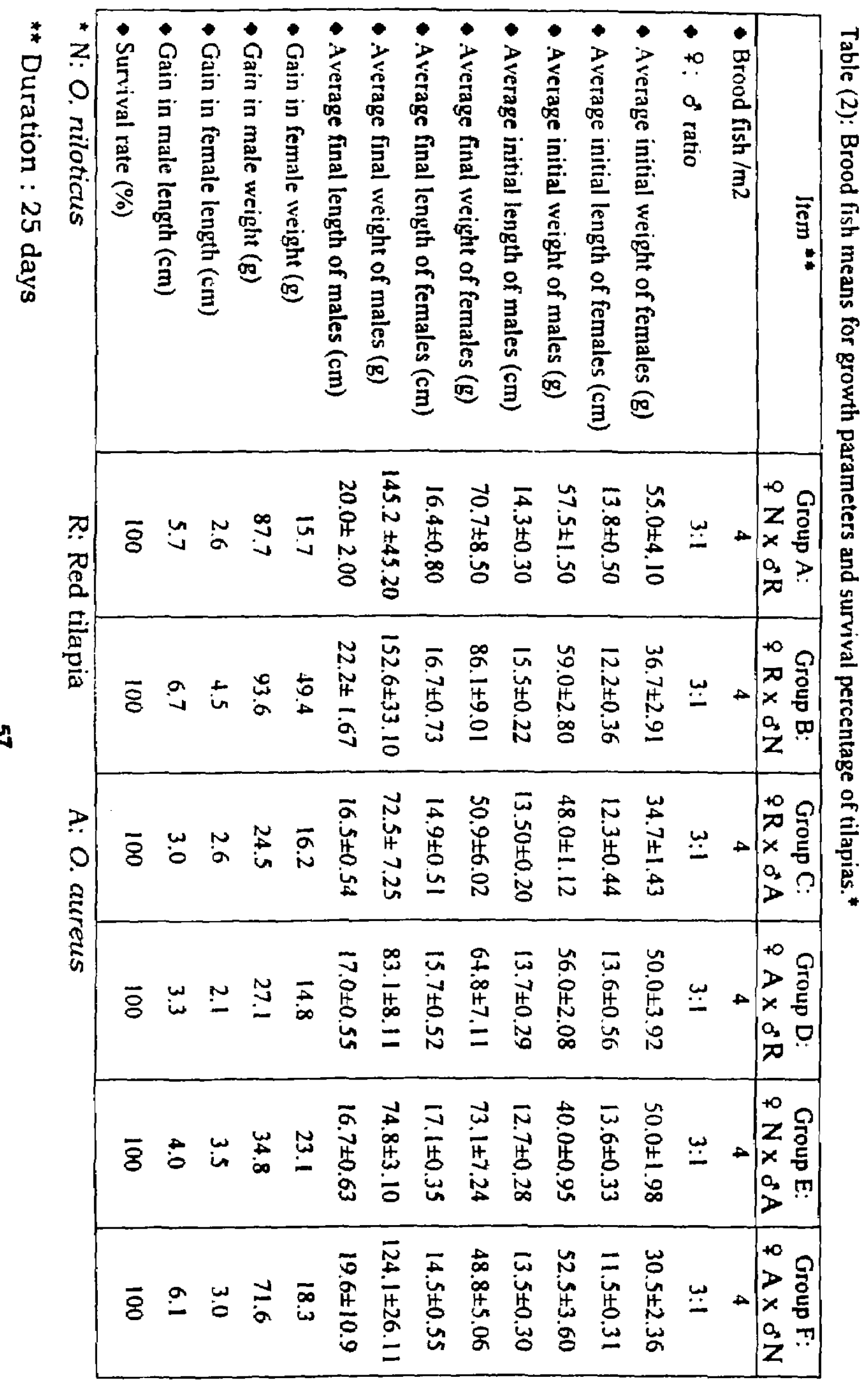


Table (3): Fry production (per female) in different tilapia crossess and the parental species. *

\begin{tabular}{|c|c|c|c|}
\hline \multirow{2}{*}{$\begin{array}{l}\text { Parent species } \\
\qquad \text { 으요 }\end{array}$} & \multirow{2}{*}{$\begin{array}{c}\text { Average fry } \\
\text { production per } \\
\text { female }\end{array}$} & \multicolumn{2}{|c|}{ Swim-up stage } \\
\hline & & $\begin{array}{c}\text { Average body } \\
\text { weight (g) }\end{array}$ & $\begin{array}{l}\text { Average body } \\
\text { length }(\mathrm{cm})\end{array}$ \\
\hline $\mathrm{N} \times \mathrm{R}$ & 1251 & 0.03 & 0.8 \\
\hline $\mathrm{R} \times \mathrm{N}$ & 989 & 0.05 & 0.8 \\
\hline $\mathrm{R} \times \mathrm{A}$ & 985 & 0.05 & 0.8 \\
\hline$A \times R$ & 981 & 0.03 & 0.9 \\
\hline$N \times A$ & 1256 & 0.03 & 0.9 \\
\hline$A \times N$ & 1073 & 0.03 & 0.9 \\
\hline $\mathrm{R} \times \mathrm{R}$ & 985 & 0.05 & 0.9 \\
\hline $\mathrm{N} \times \mathrm{N}$ & 1290 & 0.04 & 0.8 \\
\hline$A \times A$ & 986 & 0.04 & 0.7 \\
\hline
\end{tabular}

* N: O. niloticus

R: Red tilapia

A: O. aureus 
23.

Table (4): Growth performance of different tilapia hybrids and their parents during nursing period ( 90 days).*

\begin{tabular}{|c|c|c|c|c|c|}
\hline $\begin{array}{l}\text { Parent } \\
\text { species } \\
9 \times \sigma^{\pi}\end{array}$ & $\begin{array}{c}\text { Mean } \\
\text { weight gain } \\
\text { per fish } \\
\text { (g) }\end{array}$ & $\begin{array}{c}\text { Mean daily } \\
\text { wt.gain per } \\
\text { fish } \\
\text { (mg) }\end{array}$ & $\begin{array}{c}\text { Specific } \\
\text { growth rate } \\
(\% / \text { day })\end{array}$ & $\begin{array}{c}\text { Mean } \\
\text { length gain } \\
\text { per fish } \\
\text { (cm) }\end{array}$ & $\begin{array}{l}\text { Mean daily } \\
\text { length gain } \\
\text { per fish } \\
(\mathrm{mm})\end{array}$ \\
\hline $\mathrm{N} \times \mathrm{R}$ & 1.20 & 13.33 & 3.70 & 2.95 & 0.33 \\
\hline$R \times N$ & 2.27 & 25.22 & 4.06 & 3.83 & 0.42 \\
\hline $\mathrm{R} \times \mathrm{A}$ & 1.85 & 20.55 & 3.86 & 3.65 & 0.40 \\
\hline$A \times R$ & 1.10 & 12.22 & 3.92 & 2.72 & 0.30 \\
\hline $\mathrm{N} \times \mathrm{A}$ & 4.43 & 49.22 & 4.88 & 4.29 & 0.48 \\
\hline$A \times N$ & 1.85 & 20.55 & 3.92 & 3.43 & 0.38 \\
\hline$R \times R$ & 2.07 & 23.00 & 3.73 & 3.82 & 0.45 \\
\hline $\mathrm{N} \times \mathrm{N}$ & 1.91 & 21.22 & 3.98 & 3.70 & 0.30 \\
\hline$A \times A$ & 1.60 & 17.78 & 3.82 & 2.74 & 0.30 \\
\hline
\end{tabular}

${ }^{*} \mathrm{~N}$ : O. niloticus

R: Red tilapia

A: $O$. aureus 
Table (5): Condition factor, survival percentage and feed conversion ratio of different tilapia hybrids and their parents during nursing period (90 days). *

\begin{tabular}{|c|c|c|c|}
\hline $\begin{array}{c}\text { Parent species } \\
q \times \sigma^{\star}\end{array}$ & $\begin{array}{c}\text { Condition factor } \\
(\mathbf{k})\end{array}$ & $\begin{array}{c}\text { Survival } \\
(\%)\end{array}$ & $\begin{array}{c}\text { Feed conversion } \\
\text { ratio }\end{array}$ \\
\hline $\mathrm{N} \times \mathrm{R}$ & 1.88 & 85.00 & 1.02 \\
$\mathrm{R} \times \mathrm{N}$ & 2.00 & 83.00 & 1.09 \\
$\mathrm{R} \times \mathrm{A}$ & 2.00 & 85.00 & 1.36 \\
$\mathrm{~A} \times \mathrm{R}$ & 1.82 & 100.00 & 1.14 \\
$\mathrm{~N} \times \mathrm{A}$ & 2.01 & 91.00 & 1.13 \\
$\mathrm{~A} \times \mathrm{N}$ & 1.83 & 96.00 & 1.56 \\
$\mathrm{R} \times \mathrm{R}$ & 1.85 & 74.40 & 1.90 \\
$\mathrm{~N} \times \mathrm{N}$ & 2.10 & 78.30 & 1.80 \\
$\mathrm{~A} \times \mathrm{A}$ & 2.07 & 76.10 & 1.91 \\
\hline
\end{tabular}

${ }^{*} \mathrm{~N}$ : O. niloticus

R: Red tilapia

A: O. aureus 
Table (6): The heterosis values (\%) of growth parameters and survival percentage of different tilapia hybrids, during nursing period (90 days).*

\begin{tabular}{|c|c|c|c|c|}
\hline $\begin{array}{c}\text { Parent } \\
\text { species }\end{array}$ & $\begin{array}{c}\text { Mean weight } \\
\text { gain per fish } \\
\text { \& } \times \sigma^{*}\end{array}$ & $\begin{array}{c}\text { Mean length } \\
\text { gain per fish } \\
(\%)\end{array}$ & $\begin{array}{c}\text { Specific growth } \\
\text { rate } \\
(\%)\end{array}$ & $\begin{array}{c}\text { Survival } \\
(\%)\end{array}$ \\
\hline N x R & -39.70 & -24.46 & -3.90 & 11.33 \\
R x N & 14.07 & 1.86 & 5.45 & 8.71 \\
R X & 1.09 & 7.99 & 2.39 & 12.96 \\
A X R & -39.89 & -19.53 & -3.98 & 32.89 \\
N X A & 153.14 & 33.23 & 26.42 & 17.87 \\
A x N & 5.71 & 21.74 & 1.55 & 24.35 \\
\hline
\end{tabular}

* N: O. niloticus

R: Red tilapia

A: O. aureus 
rا

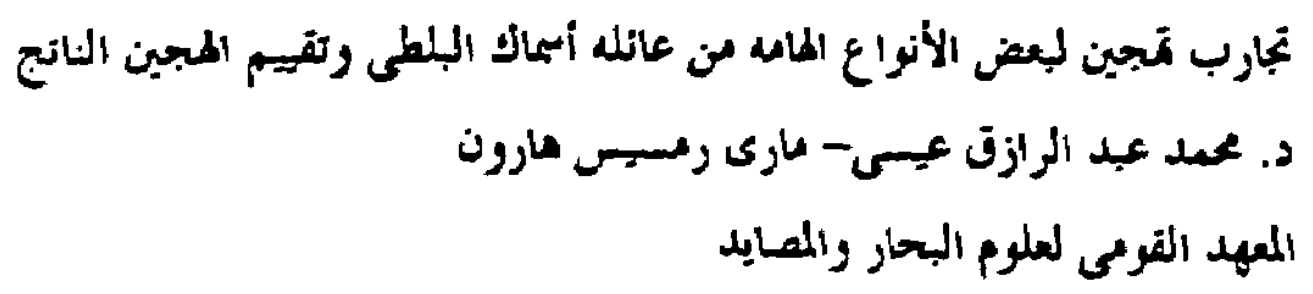

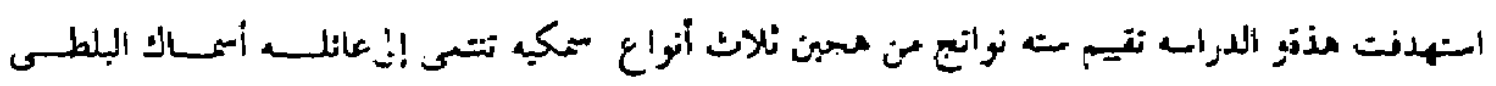

: Family Cichildae

ا. البلطى النيلى Oreochromis niloticus السريع النمو.

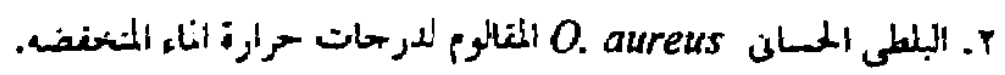

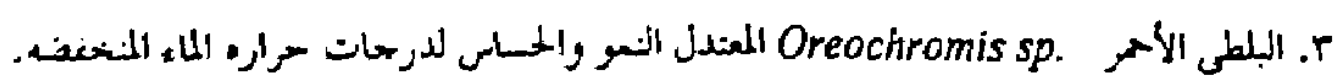

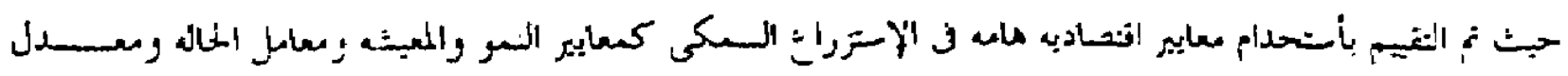

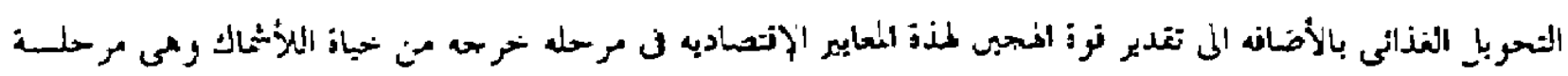

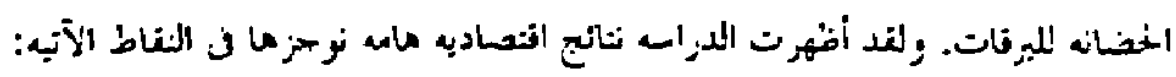

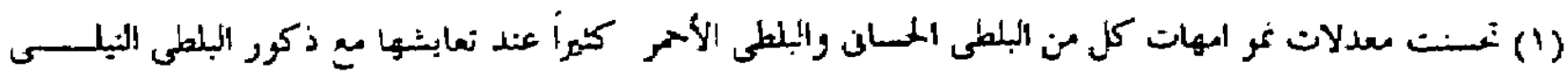
(الآباء) لوجود نوانقو ورانى ينها.

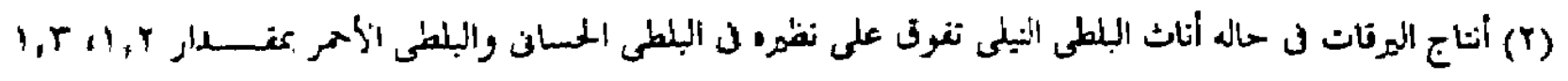
مره على الترالم.

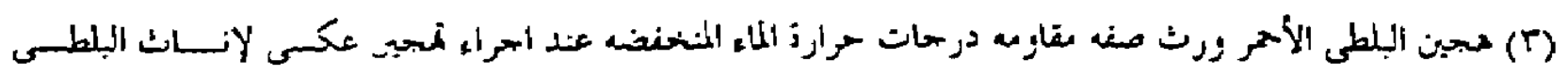
الخسائ. 


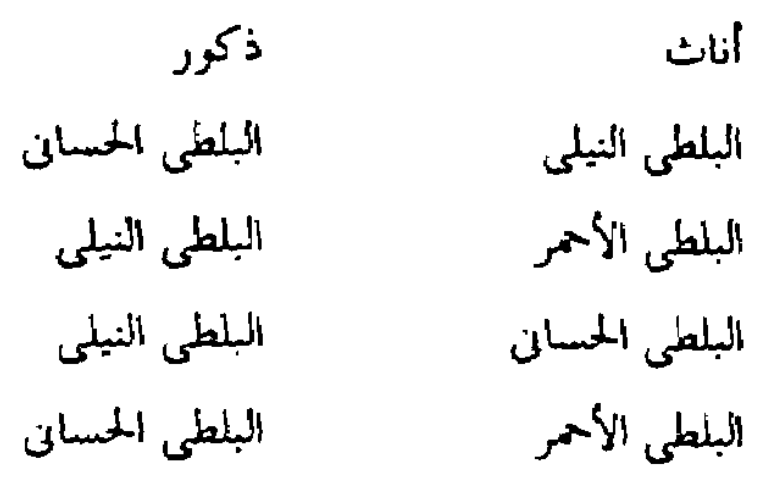

قره هجين مو هبه لمعايير النمو والمعيشه. كما ان هذا المجين استخدم كمات اقل من الغـــاء

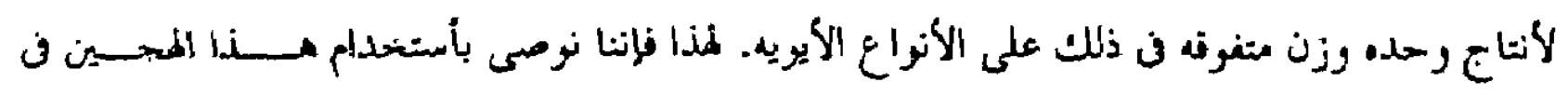

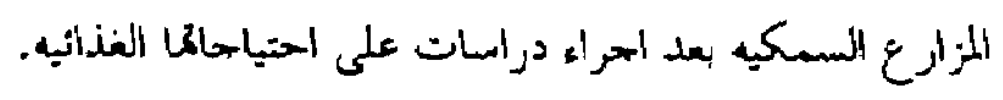

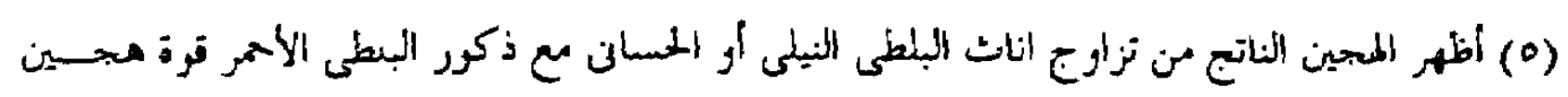

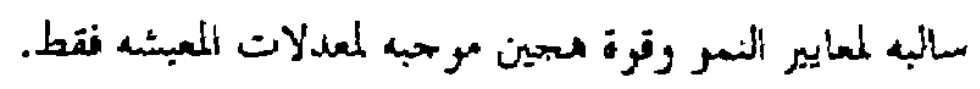

